\title{
Evaluating Public Attitudes and Farmers' Beliefs towards Climate Change Adaptation: Awareness, Perception, and Populism at European Level
}

\author{
Sandra Ricart ${ }^{1, *(\mathbb{C})}$, Jorge Olcina ${ }^{2} \mathbb{C}$ and Antonio M. Rico ${ }^{1}$ \\ 1 Water and Territory Research Group, Interuniversity Institute of Geography, University of Alicante, \\ 03690 Alicante, Spain; am.rico@ua.es \\ 2 Laboratory of Climatology, Department of Regional Geographic Analysis and Physical Geography, \\ University of Alicante, 03690 Alicante, Spain; jorge.olcina@ua.es \\ * Correspondence: sandra.ricart@ua.es; Tel.: +34-965-903-426
}

Received: 26 November 2018; Accepted: 24 December 2018; Published: 29 December 2018

\begin{abstract}
The scientific understanding of climate change is firmly established; it is occurring, it is primarily due to human activities, and it poses potentially serious risks to human and natural systems. Nevertheless, public understanding of this phenomenon varies widely among farmers and the public, the two-target audience of this paper. This paper introduces two research questions: (1) How climate change is perceived by public-farmers' nexus; and (2) How perception and populism (as a thin-ideology moved by social forces) interact? In order to address both questions, we review insights from different sources (literature, research projects, and public opinion services) over the last 10 years. The results proved how public experience of climate change is interdependent with the belief that climate change is happening. What is also notable is that the greater the years of farmers' farming experiences, the greater the percentage rate of their climate change awareness. Differences among farmers and public perceptions were also noted. Uncertainty, coupled with skepticism, the media, and political will, are common findings when asking to farmers and the public for the main weaknesses in adaptation to climate change. However, scientific consensus, meteorological data, barriers to adaptation, and the role of technology are subjects in which both differ.
\end{abstract}

Keywords: climate change; public; farmers; adaptation; perception; populism; Europe

\section{Introduction}

Global climate change is altering our relationship with the environment, modifying relatively stable climate factors and making them uncertain, unpredictable and threatening [1-3]. Changes in land use and an increasing demand for water resources have affected the capacity of ecosystems to sustain food production, ensure freshwater resources supply, provide ecosystem services and promote rural multifunctionality [4]. Ensuring food production does not just depend on increasing water efficiency, promoting crops that are more climate resilient or reducing land-use competition for urbanization. Changes in climate (precipitation, temperature, radiation, evaporation, wind) also bring major shifts in food supply [5]. The Intergovernmental Panel on Climate Change (IPCC) conducts both the Special Report on Emission Scenarios (SRES), focused on greenhouse gas emissions projections, and Representative Concentration Pathways (RCPs), a consistent set of socioeconomic, technology, and biophysical assumptions. According to them, by the 2050s climate change will increase the risk of simultaneous crop failures (including corn, rice, vegetables and legumes) if irrigation systems are not duly adapted to water stress situations [6]. A changing climate could have both positive and negative effects on crops and agriculture systems. Dinesh et al. [7] identify three major challenges to be addressed 
by the agricultural sector. Firstly, climate change affects crop productivity and food security, disrupting agricultural sector and rural livelihoods [8]. Secondly, an increase of food production is required in order to produce $60 \%$ more food by 2050 by sustaining an increasing number of smallholder farms [9]. Thirdly, up to one third of all human-caused anthropogenic greenhouse gas emissions come from agriculture, and farmers are advised to abandon vulnerable crops in the face of climate change [10,11].

Negative effects or alterations can also be extended to river systems and the rural matrix. On the one hand, these can occur through the variation of average temperatures and shifts in precipitation patterns. On the other hand, through an increase in the occurrence and intensity of meteorological extreme events (i.e., sudden floods, prolonged droughts, variation on land moisture, hurricane winds beyond the tropics) [12,13]. Both issues are expected to magnify regional differences within Europe [14]. Projected trends identify specific impacts on land and water bodies depending on Northern and Southern Europe context, as reported in IPCC Fourth Assessment Report (AR4) [15] and emphasized on IPCC AR5. According to the European Environment Agency (EEA), climate change is projected to also affect the availability and quality of water in Europe, putting additional pressure on southern regions, most of them already facing water stress. For example, in the Mediterranean region climate change affection will be focused on a decline in precipitation, soil water content, and river flow, entailing increasing plant respiration rates. In turn, this would decrease the production yield of crops and could even result in the invasion of weed, pathogens, and pests [16]. Consequently, a drastic reduction in agricultural yields can significantly hinder ensuring food security. In addition, an increased risk of biodiversity loss, more competition between different water users, or the expansion of habitats for southern disease vectors are also contemplated [17,18]. However, the situation in the Atlantic and Continental regions are clearly opposed: increase in river flow and risk of river floods and heavy precipitation events, and decrease in summer precipitation $[19,20]$.

Climate change-related threats to agriculture and rural landscapes also affect natural resources (such as water or land) at global and regional scales, and this has motivated an increasing amount of attention to the analysis of adaptation and mitigation strategies duly applied by farmers, and more interest in how the public ${ }^{1}$ values these measures and their efficiency and cost [21]. Why is public engagement with climate change and farmers' perception important? While some environmental problems appear to be more amenable to purely technical solutions [22], in democratic societies, public engagement is an added-value when addressing policies and programs able to provide mitigation and adaptation actions to climate change. For instance, stronger public engagement is a pressing priority in order to foster individual-level actions, enable people to take an active role in public debates and foster public support for climate protection policies [23]. Further, how farmers perceive climate change uncertainties and potential impacts and risks is important for two reasons. Firstly, local experience can be shared and compared through the members of the rural community and this would be useful to identify common patterns and individual strategies. Secondly, being aware of climate uncertainties, potential risks, and observed impacts on agricultural systems due to climate change is the first step towards adaptation [24].

Farmers develop their activity supporting the complexity of interrelated nature and human systems characterized by political, economic, institutional, cultural and biophysical conditions [25]. Both their actions and non-actions are also scrutinized by the public, which can support them when these actions are in line with food security and the provision of ecosystem services or criticize them when their activity provokes impacts in natural resources [26]. Personal experience, local knowledge, familiarity, and social-learning exchange between farmers and the public may help to promote mutual understanding and to reduce agricultural systems vulnerability. In addition, this could override political and social barriers to action on climate change and promote an integrated response to a shared problem: ensuring food security in a sustainable way taking into account climate change impacts [27]. Differences in levels of concern about climate change between left-wing and right-wing political parties

1 The 'public', in this context, refers to individuals who do not have an expert scientific knowledge. 
and their constituencies are well documented [28]. Support for right-wing parties and ideologies has been connected with unconcern about climate change. Consequently, right-wing populism tends to be contrary to climate policy in different regions and countries, such as USA, Australia and Europe (since 2009 political polarization about climate change increased, particularly in Anglophone countries) [29]. Consequently, both at national and European scales, their leaders and supporters are considered skeptics to the scientific mainstream [30]. According to Jäger [31], 'populism' is considered a concept with different and complementary semantic dimensions. Overseeing this multidimensional concept, two distinct approaches can be highlighted when addressing climate change issues. On the one hand, populism can be conceived as a political style, comprising the invocation of the public as the sole source of political legitimacy, although more ideologically articulated than merely contrarian politics (conceived as synonymous of 'demagoguery'). On the other side, populism can be perceived as a political tradition, characterized by anti-intellectualism and opposition to intellectual and scientific elites. Both meanings try to analyze why populists are considered climate change skeptics and contrary to climate change mitigation and adaptation policies. A possible explanation may be associated with ideological content and cultural cognition, in which political agreements, meteorological data and experts' opinion are used to support or refuse scientific statements on climate change (see Figure 1) [32]. This idea is included in the analysis of cognitive bias and judgement heuristics conducted by Dunn et al. [33], in which both factors are considered key issues when influencing individuals. One such bias to be applied on farmers and public profiles is the "optimistic bias" or "unrealistic optimism" in which people tend to perceive their own risk of being affected by a particular threat (any type of climate change impact) to be smaller than the average risk supported by the community.

Adaptation to climate change impacts and risks can be limited due to different factors, including the lack of detailed information about climate change effects; political weakness in decision-making processes at local scale; confronted interests from socioeconomic and environmental opposed priorities; the inefficiency of existing policies; or the role of scientists and experts [34]. This last limitation put the focus on how lessons learned by scientists could be useful for farmers and positively perceived by the public. In fact, two main constraints have been identified when asking for climate scientists and experts' roles. Firstly, climate scientists and environmentalists could be considered corrupted (i.e., conflict-of-interest accusations ${ }^{2}$ ). Secondly, climate change understanding is complex, involving different research disciplines, economic sectors and activities, or environmental risks, and this context is ideal for promoting conspiracy theories (i.e., the 'Climategate' case, in which climate change scientists are accused of manipulating data to promote climate change as human-caused) $[35,36]$. This public accusation could be favored by the tendency to rely on indirect sources of information when asking for climate change issues, more than considering personal experience as starting point for promoting climate change action [37]. Consequently, public profiles could be divided among those who believe in anthropogenic climate change, assuming that immediate action should be taken (catastrophists), and those who consider climate change as natural fluctuation, assuming that actions should be taken on a voluntary base (negationists) [38]. This paper aims to analyze the complex relationships between farmer beliefs and public claims for climate change perception, by deepening on concerns about social vulnerability and adaptation and perspectives on climate change actions and policies in the last 10 years. While previous research has investigated the farmers' attitudes towards climate change risks and adaptation issues [39] or compared farmers' perception of climate change with meteorological data [40], little research has explored public perception. Even less common are studies that compare the attitudes and preferences of farmers with that of the public. According to this, two main questions will be addressed: (1) How climate change is perceived by public-farmers' nexus; and (2) How perception and populism interact?

2 Most of this information has been published in newspapers: "Work of prominent climate change denier was funded by energy industry" (Suzanne Goldenberg, 2015, The Guardian) or "Deeper ties to corporate cash for doubtful climate researcher" (Justin Gillis and John Schwartz, 2015, The New York Times). 


\begin{tabular}{|c|c|c|c|c|c|c|c|c|c|c|}
\hline 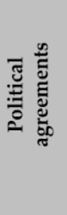 & $\begin{array}{l}\text { COP 14 } \\
\text { Climate } \\
\text { change is } \\
\text { a priority } \\
\text { for the } \\
\text { economy }\end{array}$ & $\begin{array}{c}\text { COP 15 } \\
\text { Copenhagen } \\
\text { Accord: } \\
\text { comprehensive } \\
\text { adaptation } \\
\text { program }\end{array}$ & $\begin{array}{l}\text { Green In } \\
\text { Climate } \\
\text { Fund }\end{array}$ & $\begin{array}{c}\text { Implementation } \\
\text { of the } \\
\text { Kyoto } \\
\text { Protocol }\end{array}$ & $\begin{array}{c}\text { Adaptation, } \\
\text { loss and } \\
\text { damages } \\
\end{array}$ & $\begin{array}{l}\text { Warsaw } \\
\text { International } \\
\text { Mechanism } \\
\text { for Loss and } \\
\text { Damage }\end{array}$ & $\begin{array}{c}\text { Global } \\
\text { temperature } \\
2^{\circ} \text { Celsius } \\
\text { above } \\
\text { current } \\
\text { levels }\end{array}$ & $\begin{array}{c}\text { Paris } \\
\text { Agreement } \\
\text { Limit } \\
\text { temperature } \\
\text { increase to } \\
1,5^{\circ} \text { Celsius }\end{array}$ & $\begin{array}{c}\text { FAO support } \\
\text { Global } \\
\text { Infrastructure } \\
\text { Basel } \\
\text { Foundation }\end{array}$ & $\begin{array}{l}\text { COP } 23 \\
\text { Mobilising } \\
\text { expertise, } \\
\text { technology } \\
\text { and support } \\
\text { to climate } \\
\text { change } \\
\text { victims }\end{array}$ \\
\hline \multirow{3}{*}{ 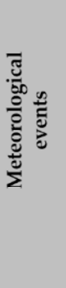 } & 2008 & 2009 & 2010 & 2011 & 2012 & 2013 & 2014 & 2015 & 2016 & 2017 \\
\hline & $\begin{array}{c}\text { Northern } \\
\text { hemisphere } \\
\text { land } \\
\text { temperature: } \\
5^{\text {th }} \text { warmest }\end{array}$ & $\begin{array}{l}\text { Unusually } \\
\text { cold } \\
\text { European } \\
\text { winter }\end{array}$ & $\begin{array}{c}19 \text { countries } \\
\text { (20\% global } \\
\text { land area) } \\
\text { experienced } \\
\text { their hottest } \\
\text { recorded } \\
\text { year }\end{array}$ & $\begin{array}{l}\text { Global } \\
\mathrm{CO}_{2} \\
\text { emissions } \\
\text { reach new } \\
\text { all-time } \\
\text { high in } \\
2011\end{array}$ & $\begin{array}{c}\text { Sea surface } \\
\text { temperature } \\
\text { for } 2012 \\
\text { was among } \\
\text { the } 11 \\
\text { warmest on } \\
\text { record }\end{array}$ & $\begin{array}{c}\text { Southern } \\
\text { Europe's } \\
\text { wet } \\
\text { winter ( } 2^{\circ} \\
\text { wettest } \\
\text { since } \\
1948)\end{array}$ & $\begin{array}{c}\text { Earth's } \\
\text { warmest } \\
\text { year since } \\
1880 \\
\\
\text { Europe's } \\
\text { record warm }\end{array}$ & $\begin{array}{c}\text { Europe's } \\
\text { second } \\
\text { warmest } \\
\text { year } \\
\text { Great Britain, } \\
\text { Ireland and } \\
\text { France floods }\end{array}$ & $\begin{array}{c}\begin{array}{c}\text { Europe's } \\
\text { third } \\
\text { warmest year }\end{array} \\
\text { Winter Arctic } \\
\text { sea ice extent } \\
\text { in } 2016\end{array}$ & $\begin{array}{c}\text { Summer's } \\
\text { record heat } \\
\text { across } \\
\text { Southern } \\
\text { ic } \begin{array}{c}\text { Surope' } \\
\text { it }\end{array}\end{array}$ \\
\hline & 2008 & 2009 & 2010 & 2011 & 2012 & 2013 & 2014 & 2015 & 2016 & 2017 \\
\hline 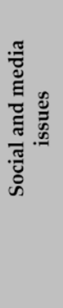 & $\begin{array}{l}\text { EU told to } \\
\text { prepare for } \\
\text { flood of } \\
\text { climate } \\
\text { change } \\
\text { migrants } \\
\text { (I. Traynor, } \\
\text { The } \\
\text { Guardian) }\end{array}$ & $\begin{array}{c}\text { Climatic } \\
\text { Research } \\
\text { Unit email } \\
\text { controversy } \\
\text { (Climategate) } \\
\text { Al Gore } \\
\text { 'profiting' from } \\
\text { climate change } \\
\text { agenda } \\
\text { (N. Allen, The } \\
\text { Telegraph) }\end{array}$ & $\begin{array}{c}\text { Climate } \\
\text { change } \\
\text { hots up in } \\
\text { 2010, the } \\
\text { year of } \\
\text { extreme } \\
\text { weather } \\
\text { (J. Vidal, } \\
\text { The } \\
\text { Guardian) }\end{array}$ & $\begin{array}{c}\text { Climate } \\
\text { change } \\
\text { threatens } \\
\text { Europe's } \\
\text { living } \\
\text { standards } \\
\text { (N. Jones, } \\
\text { Nature) }\end{array}$ & $\begin{array}{c}\text { Climate } \\
\text { change is } \\
\text { here, and } \\
\text { worse than } \\
\text { we thought } \\
\text { (J.E. Hansen, } \\
\text { The } \\
\text { Washington } \\
\text { Post) }\end{array}$ & $\begin{array}{l}2013 \text { in } \\
\text { review: a } \\
\text { year of } \\
\text { increasing } \\
\text { extreme } \\
\text { weather } \\
\text { events } \\
\text { (J. Vidal, } \\
\text { The } \\
\text { Guardian) }\end{array}$ & $\begin{array}{l}\text { It's official: } \\
\text { Summer } \\
2015 \text { was } \\
\text { the hottest } \\
\text { ever } \\
\text { experienced } \\
\text { in Spain } \\
\text { (J. Jones, The } \\
\text { Local) }\end{array}$ & $\begin{array}{c}\text { New York } \\
\text { State Sues } \\
\text { Exxon Mobil } \\
\text { for } \\
\text { Misleading } \\
\text { Investors } \\
\text { Regarding } \\
\text { Climate } \\
\text { Change } \\
\text { (E. Larson, } \\
\text { TIME) }\end{array}$ & $\begin{array}{c}\text { Paris } \\
\text { floods as } \\
\text { River Seine } \\
\text { approaches } \\
\text { record- } \\
\text { level rise } \\
\text { (M.L. } \\
\text { Nestel, ABC } \\
\text { News) ar } \\
\end{array}$ & $\begin{array}{l}\text { Trump-O- } \\
\text { Meter: } \\
\text { Cancelled the } \\
\text { Paris climate } \\
\text { agreement } \\
\text { (L. Jacobson, } \\
\text { Politifact.com) } \\
\text { Climate denial } \\
\text { and the populist } \\
\text { right } \\
\text { A. Norton, IIED) }\end{array}$ \\
\hline
\end{tabular}

Figure 1. Main political, meteorological, and social and media issues about climate change perception. Source: Meteorological events were selected according to three criteria: diversity (different typology of events), relevance (included in IPCC reports), and social recognition (disseminated by the media). Newspapers and webpage consultation (www.noaa.gov, www.climate.gov, www.climatecentral.org, www.wri.org, www.climateanalytics.org, www.politifact.com). Note: COP means (Conference of the Parties) and it is the supreme body of the United Nations Framework Convention on Climate Change (UNFCCC). It holds its sessions every year in order to take decisions that are necessary to ensure the effectiveness of adaptation policies implementation. During COP24, taking place in Poland on December 2018, the main objective will be to adopt a decision ensuring full implementation of the Paris Agreement in order to give the Paris Agreement a realistic shape by setting out a path that each country will decide to follow in terms of intensifying its climate protection efforts. Three key topics will be addressed: (1) technology (presenting climate-friendly modern solutions); (2) human (emphasizing the need to lead change together with people through the solidarity and fair transformation of regions and industrial sectors); and (3) nature (including multifunctional and sustainable land management and support for a synergic view of the three United Nations key conventions: on climate, on biodiversity and on desertification.).

\section{Materials and Methods}

According to Hulme et al. [41], confronted discourses, perceptions and attitudes about climate change can be mapped and analyzed based on complementary sources. Discussions in the media, advances in scientific journals, political speeches and international negotiations, or public responses and social attitudes after an extreme event associated with climate change can provide useful information and specific details on how climate change is motivating a debate that surpasses the geographic context and the scientific and technical focus [42]. In line with this argument, the review process for this study included different sources: (1) literature to address farmers' perception, (2) public opinion surveys (Eurobarometer) to deepen on social attitudes, and (3) EU research projects to complement both previous sources.

\subsection{Literature}

The analysis of the literature has been focused in two main databases: Web of Science and Scopus. Both databases were selected due to their availability as the most current, powerful, comprehensive and widely used search engines for peer-reviewed literature [43]. In each database, search processes included the use of OR operator for technical aspects (impacts, barriers, scenarios) and the use of AND 
operator for social terms (attitudes, beliefs, perception). Both operators have been fixed as part of the title of the paper. In order to identify relevant literature, we used the following search terms to ensure a complex search string focused on the combination of technical and social components related to public and farmers' perception, attitudes and beliefs about climate change from 2008 to 2017, limited to European context. Search items have been applied on "title" search topic more than in "subject" search topic when using databases. Specific keywords are used and combined as follows (*represents a search engine wild card):

Technical terms: climate change, scenario*, projection $^{*}$, impact ${ }^{*}$, barrier $^{*}$, adapt ${ }^{*}$

Social terms: percept ${ }^{*}$, attitude ${ }^{*}$, belief ${ }^{*}$, populism, scept ${ }^{*}$, support ${ }^{*}$, denial ${ }^{*}$, benefi ${ }^{*}$, particip*, polic ${ }^{*}$, soci* farm* ${ }^{*}$ agric*, irrigat*, stakeholder*

Returned papers were considered based on the inclusion criteria at three successive levels: title, abstract and full-text. On each level, the achievement of the content analysis to each or more than one criterion was examined (Table 1). Papers clearly focused on climate change perceptions, attitudes and positive or negative adaptation attitudes issues, and those including transversal analysis from social sciences such as Geography, Political Science, Economics and Sociology, to physical and life sciences such as Agriculture, Hydrology, Earth and Environmental Sciences, have been selected.

Table 1. Admission/exclusion criteria used in literature search terms process.

\begin{tabular}{ccc}
\hline Criteria & Include & Exclude \\
\hline Peer-reviewing & Peer-reviewed & Everything else \\
Year & $2008 \leq \mathrm{Y} \leq 2017$ & Everything else \\
Geo-location & Europe, regions & Everything else * \\
Text language & English & Everything else \\
Subject & Agriculture, environment, climate change & Urban, landscape \\
Method & Qualitative, mixed & Only quantitative ** \\
Highlighted topics & Perception, adaptation, barriers, politics & Only natural sciences \\
\hline
\end{tabular}

Note: Adapted from [44,45] * Non-European studies have been used to be compared on perception analysis. ** Literature exclusively focused on using quantitative methods and tools (such as cause-effect relation, mathematical formulas, modelling, or statistics) have been excluded from the analysis.

The initial database search retrieved 1331 documents according to advanced search tools (Table 2). Only records from peer-reviewed journals (article and review papers) were included for the analysis. Therefore, books and book chapters, proceedings papers, $\mathrm{PhD}$ thesis, research project reports, or industry and government documents were excluded, but can be used for identifying key issues not previously analyzed. After screening for social terms, articles able to move on to the next step were reduced to 830 papers ( $62.4 \%$ of the initial amount). All of them were selected from research criteria number 1, which comprised the reading of article titles, abstracts and keywords. Papers from technical terms have been consulted irregularly. The title analysis applied to each database excluded 338 papers for different reasons: (a) papers were not clearly related to climate change effects on agriculture, land systems nor irrigation (i.e., off-topic papers), (b) papers only focused on technical aspects (i.e., climate change scenarios and projections; land and water uses for mitigation actions), (c) not specific to Europe. In addition, a cross-match of the title analysis was done to identify and remove duplicated papers (204 papers). From 492 papers selected in title analysis, only 288 papers moved to the abstract level of analysis. During the abstract reading, 195 papers were excluded due to the lack of combination of technical and social terms (i.e., papers focused on policy analysis, technical innovations, and mitigation actions). However, some papers have been used to compare European results with global tendencies. Completing the final level of the reviewing process, 93 papers were selected and the research criteria number 2 have been applied. Full-text analysis has been conducted according to the topic: main driving factors of climate change perception and populism from public attitudes and farmers' beliefs. Some limitations of this method must be recognized. On the one hand, obtained results are restricted by the 
keyword combinations used. On the other hand, interesting papers published after the analyzed period are only referenced in the Discussion section. Finally, using only the two main research databases (Web of Science and Scopus) excluded secondary relevant publications, some of them very interesting from the point of view of regional case studies.

Table 2. Papers selected from database search analysis.

\begin{tabular}{cccccccc}
\hline Database & $\begin{array}{c}\text { Initial } \\
\text { Search }\end{array}$ & $\begin{array}{c}\text { Criteria 1: } \\
\text { Technical Terms }\end{array}$ & $\begin{array}{c}\text { Criteria 2: } \\
\text { Social Terms }\end{array}$ & $\begin{array}{c}\text { Title } \\
\text { Analysis }\end{array}$ & $\begin{array}{c}\text { Duplicated } \\
\text { Papers }\end{array}$ & $\begin{array}{c}\text { Abstract } \\
\text { Analysis }\end{array}$ & $\begin{array}{c}\text { Full-Text } \\
\text { Analysis }\end{array}$ \\
\hline Web of & 857 & 341 & 516 & 250 & - & 250 & 116 \\
Science & 474 & 160 & 314 & 242 & 204 & 38 & 49 \\
Scopus & 1331 & 501 & 830 & 492 & 204 & 288 & 93 \\
TOTAL & 130 &
\end{tabular}

Note: The research category selection was specific for each database. In Web of Science the selected research categories were Agriculture, Biodiversity and conservation, Environmental Sciences \& Ecology, Food Science \& Technology, Meteorology \& Atmospheric Sciences, Water resources, Geography, Government \& Law, and Sociology. In Scopus, we selected similar categories: Agricultural and biological sciences, Environmental sciences, Social science, Earth and planetary sciences, engineering, Economics, econometrics, and finance.

\subsection{Public Opinion Services (Eurobarometer)}

Eurobarometer is a series of public opinion surveys conducted regularly on behalf of the European Commission since 1973 [46]. Its mission is monitoring the public opinion of member states at European level by using telephone or face-to-face interviews and digital questionnaires. The Eurobarometer program comprises different survey series or instruments, including Special Topic Eurobarometer. These intermittent surveys extensively address a wide variety of topical issues such as agriculture, biotechnology, energy, environment, gender roles, immigration, information society, poverty and social exclusion, public health, or urban traffic, providing results every two to three years. From 178 special surveys published in the last 10 years, those special issues related to climate change, the environment and biodiversity, and agriculture and the Common Agricultural Policy (CAP) have been selected for this study based on the inclusion of "climate change" as topic and/or as part of the respondents' answers. Fifteen opinion surveys have been used for this analysis: seven surveys related to climate change, four surveys related to environment and biodiversity, and four surveys related to agriculture and the CAP (Table 3). The main questions addressed by the surveys are focused on: (1) Public perceptions of the seriousness of climate change, (2) The extent to which the public feel informed about climate change, (3) Public attitudes towards climate change and ways of combating it, and (4) Agriculture-environment nexus to climate change. In this repeated cross-sectional design, data were collected from 2008 to 2017.

In each year, a multi-stage random sample was drawn from approximately 1000 face-to-face interviews per country with individuals aged 15 years and older of the European Union Member States. The basic sample design applied in all states is a multi-stage, random (probability) one. In each country, a number of sampling points was drawn with probability proportional to population size (for a total coverage of the country) and to population density. In order to do so, the sampling points were drawn systematically from each of the "administrative regional units", after stratification by individual unit and type of area. They thus represent the whole territory of the countries surveyed according to the EUROSTAT NUTS II (or equivalent) and according to the distribution of the resident population of the respective nationalities in terms of metropolitan, urban and rural areas. In each of the selected sampling points, a starting address was drawn, at random. Further addresses were selected by standard "random route" procedures, from the initial address. All interviews were conducted face-to-face in people's homes and in the appropriate national language. As far as the data capture is concerned, CAPI (Computer Assisted Personal Interview) was used in those countries where this technique was available. 
Table 3. List of Specials Topic Eurobarometer analyzed from European Commission survey data.

\begin{tabular}{ccc}
\hline Special Topic & Reference Numbers & Years \\
\hline Climate change & $459,435,409,372,322,313,300$ & $2017,2015,2014,2011,2009 *, 2009,2008$ \\
Environment & $468,436^{* *}, 365,295$ & $2017^{* * *}, 2015,2011,2008$ \\
Agriculture and the CAP & $473,440,410^{* * * *}, 336$ & $2018,2016,2014,2010$ \\
\hline
\end{tabular}

Note: In $2009 *$ a second survey was conducted in August-September according to world leaders meeting at the United Nations Climate Change Conference (COP15) in Copenhagen in December to try and reach a follow-up agreement to the Kyoto Protocol. ${ }^{* *}$ This report is focused on biodiversity, and key questions are different from environmental reports. *** The fieldwork conducted for the Special Topic 473 was conducted during 2017. **** This report is not analyzed because "climate change" issue only appears in one sentence: "important objectives of the $\mathrm{CAP}$ are food security, the sustainable management of natural resources, the preservation of rural economies, the redistribution of aid between countries and between farmers, and climate change" (Introduction, p. 2).

\subsection{EU Research Projects}

In combination with Sustainable Development Goals and Circular Economy initiatives, European Commission policy addresses research on topics such as climate action as one of the most challenging problems confronting society [47]. Thematic initiatives focused on the scientific, technical, environmental, economic and social aspects of climate change vulnerability (sensitivity and adaptability) have been developed in recent years [48]. Among them, two research programs stand out when analyzing climate change perception, politics and populism issues: Seventh Framework Programme for Research and Technological Development (FP7) and Joint Programming Initiative (JPI). In the first case, the Community Research and Development Information Service (CORDIS) database has been used to identify and select research projects funded between 2007 and 2013 (and according to this, final reports and main research advances have been already published) that include some type of analysis on climate change perception. A search on farmers and/or public perception has been conducted following data search portal and using search refinement (program: FP7-Environment; subject: climate change and carbon cycle research; and content type: projects). In addition, other subjects such as "agriculture" and "social sciences and humanities" have also been considered without obtaining positive results. Three ${ }^{3}$ of 27 research projects have been identified since they include perceptual analysis of climate change (focused on public consultation and debates). A deeper analysis of these projects has not provided sufficiently positive results to be considered more than a complementary research source. In the second case (JPI Climate), 2013 Call for transnational collaborative research projects (topic on societal transformation in the face of climate change) has been analyzed. One of six funded projects has been selected for deepen analysis: European perceptions of climate change: Skepticism, energy preferences and societal information (EPCC, 2014-2017). For each selected research project, main deliverables (reports, publications, policy briefs, participation feedback) published on the project website have been analyzed in order to deepen on main obtained highlights.

\section{Results}

\subsection{How Farmers Perceive Climate Change?}

Factors influencing farmers' decisions to adapt to climate change variability and potential risks have been analyzed through a large body of literature, identifying a certain level of dependency on climate change stimuli.

3 Action on climate change through engagement, network and tools (ACCENT, 2009-2011); Climate change and European marine ecosystem research (CLAMER, 2009-2011); Impacts and risks rom high-end scenarios: Strategies for innovative solutions (IMPRESSIONS, 2013-2018). 


\subsubsection{Awareness, Uncertainty and Beliefs about Climate Change}

The vast majority of studies identify a clear awareness of how impacts of climate change are perceived at local scale [49-51]. In fact, research has tracked trends in public knowledge about and perception of climate change without directly asking for the difference between being aware of the potential risks and impacts of climate change and being aware of the uncertainties surrounding these [52]. According to Withmarsh [53], policy actors tend to downplay or ignore scientific uncertainty about climate change and reject alternative societal perspectives on the issue. Moreover, climate change information campaigns by governments and environmental groups similarly use the language of certainty and focus on the most dramatic and even apocalyptic scenarios which unchecked climate change could bring [54]. Conversely, some studies show how extreme weather events affect climate risk perceptions [55], while others deepen on how economic downturns do not uniformly have the widely expected negative effect on support for climate mitigation policies [56]. In most cases, such as the study of Chingala et al. [57], awareness is in line with meteorological variations but there was a general uncertainty towards a number of climate change related statements [58]. This is particularly obvious in the study of Barnes and Toma [59], in which a set of questions have been formulated. In one of these questions, the authors ask about the possibility that climate change only impacts negatively in the long term, obtaining high levels of ignorance and lack of information from the respondents. In the study of Gordon et al. [60], climate change belief and attribution variable revealed that most farmers believed that climate change is occurring. Although in the majority of studies human activities are the causative factor of climate change [61-63], in some papers, farmers consider that climate change is caused by natural changes and human activities equally, causing affects regional land-use and water resources [64].

\subsubsection{Perceived Climate-Related Risks and Sensitivity}

Farm level operations are limited by various risks directly related to climate change impacts and natural resources changing conditions. One of the main results obtained from the literature is the consensus on the main climate-related observed impact: extreme maximum temperature in summer and extreme minimum temperature in winter. The consequences of both scenarios are also recognized. Extreme maximum temperature in summer can cause a reduction in pollination and effects to productivity. On the opposite, extreme minimum temperature may affect the nighttime plant respiration rates, which can potentially reduce biomass accumulation during the growth stage, and hence the crop yield [65]. In addition, a general perception among the farmers is that the amount of annual rainfall received decreased and ambient temperatures roses over the past two decades [66]. Similar results have been obtained in the work of Galdies et al. [67] in which the main belief of farmers is that warmer conditions are clearly leading to negative climate change impacts. The multiple-mediation models conducted by Haden et al. [68] also indicate how suffering water scarcity in the past motivates farmers' concern for local water availability, and this increases their motivation to fight climate change. For example, a study conducted by Deligios et al. [69] shows how, also in environmental limiting conditions, producers could opt for a significant saving in water supply to the crop in order to maximize and stabilize over seasons the crop yield, to obtain satisfactory yields. This better environmentally-friendly management of water, which combines tradition (social-learning) and innovation (water efficiency technology), can improve the quality of life for future generations and also increase greater public belief that climate change poses a serious threat to both farmers and themselves [70]. However, water scarcity perception and meteorological data on rainfall statistics may differ, causing a false sensation in which farmers will be more worried about the rainfall availability during the main crop-growing season because it is the period in which water is needed, but without knowing the total rainfall received in their area annually [71,72]. In fact, despite being exposed to similar information, local experiences, and adapting measures, both farmers and the public tend to perceive climate change in different ways due to economic, environmental, cultural, and political implications of climate change are not uniform [73]. 


\subsubsection{Skepticism, Obstacles and Barriers}

Society needs to confront important issues in the near future, in which climate change is ranked below topics such as food security or water-energy nexus [74]. Different reasons motivated this situation: issue fatigue (many discussions without applying clear actions), the impact of the global financial crisis, distrust in scientists and experts, and politicization motivated by skepticism [75]. This last factor has been one of the main topics included in several studies, in which age and education are important determinants of skepticism about climate change [76], but also differences in values and worldviews [77], and media-generated controversy [78]. Political ideology (or affiliation), and membership of environmental organization were non-significant predictors of climate change skepticism [79]. However, studies conducted by Häkkinen and Akrami [80] conclude that farmers' skepticism of climate change correlates with lower political participation, taking into account climate change communications regardless of ideological position. This correlation might be motivated by the inclusion of pro-environmentalism values as part of the local government mainstream, for example [81].

\subsubsection{Mitigation and Adaptation Measures}

Some measures have been promoted to ensure farmers' adaptation to climate change impacts: Social awareness, investment in new heat-tolerant varieties, crop insurance, and support and protection programs are the main issues driven by farmers [82]. Considering climate change from its anthropogenic nature, the adaptation of agricultural practices was perceived as a collective responsibility shared by scientists and farmers. Consequently, scientists must develop more climate-resilient crops by providing extension services to supply new land and soil management practices $[83,84]$, while farmers must consider adaptation measures as a mechanism to provide new food products in line with market trends and social demands [85]. Both responsibilities are based on the belief that climate change was already happening and most adaptation statements are confirmed by end-users, including the use of drought-resistant crops, efficient use of water, a change in cultivation patterns, relocation of crops varieties, and effective use of fertilizers and pesticides [86]. According to Ochieng et al. [87] and Kibue et al. [88], the type of adaptation can be divided into different issues. Firstly, changing cropping practices (introduction of new varieties, changing planting dates). Secondly, improving farm management practices (limited use of fertilizers/pesticides and efficiency in water supply by investing in innovative farming technologies). Finally, introducing land management measures (soil conservation, tree plantation).

\subsubsection{Support for Action, Trust, and Political Issues}

Most studies are focused on addressing direct and indirect questions to farmers as a way to indeed on their attitudes about the role and efficiency of local governments when providing different services and support actions related to climate change adaptation. Absence of public supporters working for farmers' interests is perceived as one of the main concerns expressed by the majority of the farmers $[89,90]$. Although most farmers are aware of the role of local authorities in providing information about the affection of climate change, they reclaim more details concerning how risks arising from climate change can be reduced [91]. In addition, studies like those conducted by Hobson and Niemeyer [92] call for combining information with political leadership: without which, farmers and individuals are less likely themselves to respond to attempts to adapt to climate change. Engels et al. [93] identified a positive correlation between climate-change skepticism, low social status and old age, but also to political party linked to conservatism. In fact, political and cultural context defines most of the factors involved in climate-change skepticism approaches [94]. According to Hornsey et al. [95], farmers do not usually follow this rule, and the findings provided by the study of Guy et al. [96] indicate that knowledge and information can play a key role in limiting the impact of political ideologies on farmers' opinions of climate change. However, polarization of political discourses can increase the harshness between opposing opinions, especially in those contexts where 
there is a clear opposition to change [97]. Sometimes, this rejection to change can be explained by the nexus between rural development and farmers' identity (i.e., by promoting farming practices capable of representing the roles, values, and identity of rural communities), as suggested by Feola et al. [98]. A synthesis of the main issues considered by farmers when explaining their perception on climate change risks and challenges are detailed in Figure 2. Farmers considered that questions about scientific consensus and political will are positive issues when addressing climate change, while knowledge gaps, skepticism, and meteorological vulnerability are considered main limitations to achieve climate change adaptation.
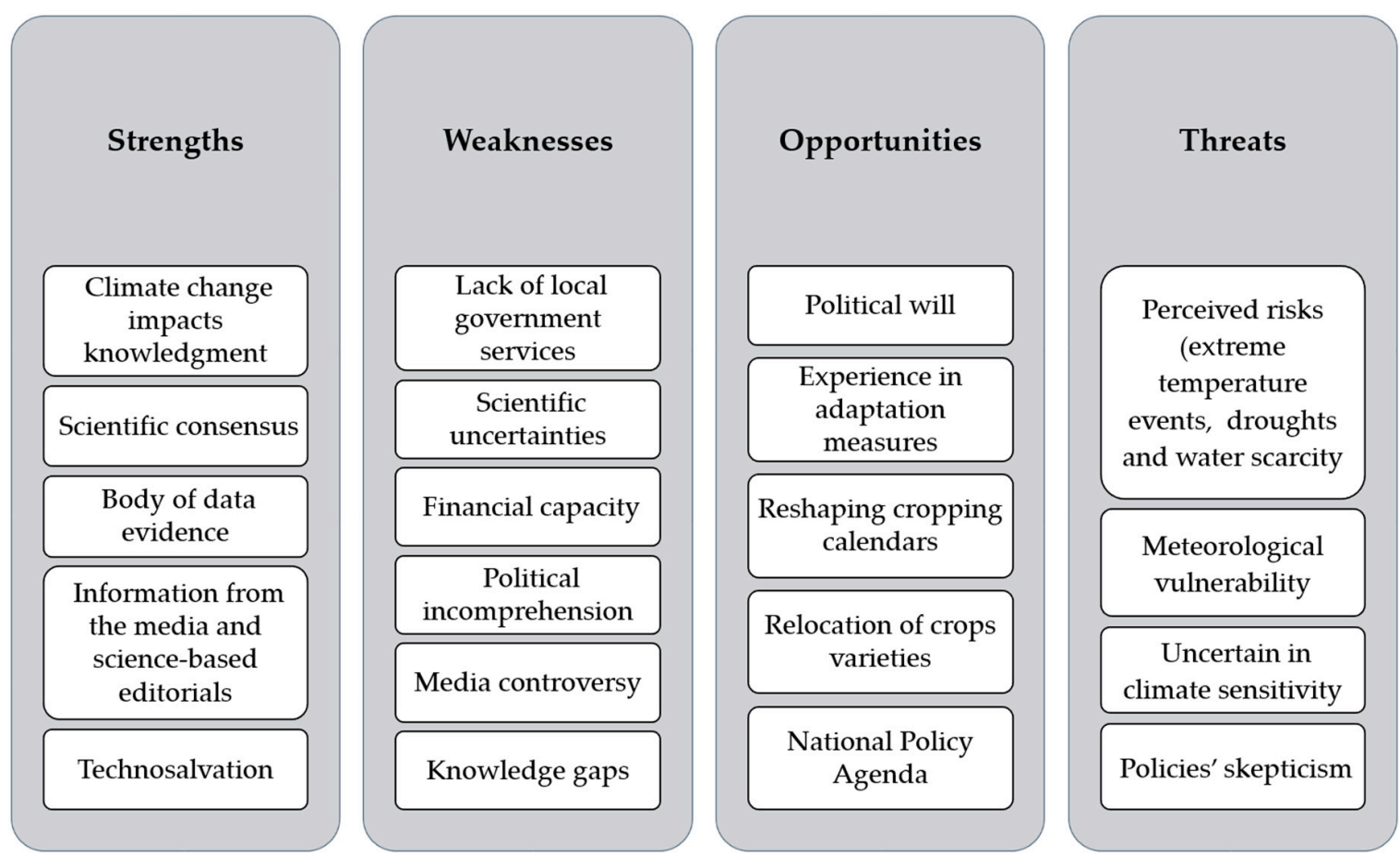

Figure 2. SWOT analysis including the main issues considered by farmers when addressing climate change perceptions. (Source: Own elaboration from literature review.).

\subsection{How the Public Perceives Climate Change and Farmers' Role?}

The invisibility of the causes that have motivated climate change and the difficulty of predicting or adequately analyzing the impacts of climate change and their dissemination justifies a lack of temporal and geographic comprehension [99]. According to Hagen et al. [100], although the public largely supports policy action to address climate change, they are contrary to individual tax measures. In order to deepen on these questions, public perceptions have been analyzed by combining Eurobarometer reports and EU research projects.

\subsubsection{Climate Change Reports}

In-depth analysis of Eurobarometer reports on climate change have been structured in two main questions:

Question 1: climate change as a serious world problem

This question is divided in three specific subjects: (1) Concern about climate change as one of the most serious problems at world level, (2) Level of seriousness of global warming / climate change on a scale from 1 to 10, and (3) Socio-demographic variables and social profiles. According to the reports, climate change is currently ranked third (43\%) in the list of the most serious world problems (behind poverty, hunger and lack of drinking water, and international terrorism), while ten years ago climate change was ranked second (62\%). Despite this decline in relevance, the degree of seriousness (concern) 
attributed to climate change has increased (from 7.5 in 2008 to 7.7 in 2017), especially since 2015 (Paris Agreement) (Figure 3). In terms of socio-demographic profile, women are more likely to describe climate change as a serious problem (average score of 7.5 compared to 7.2 amongst men). Older citizens are less concerned, with those aged 55 and over giving on average a score of 7.2 compared to 7.4/7.5 amongst younger citizens. Similarly, retired people tended to view the issue less seriously. This result is in line with the Climate change and European marine ecosystem research (CLAMER) project, conducted between 2009 and 2011 with the aim of assessing the publics' perception and knowledge of EU research on climate change impacts. Although the project is focused on marine ecosystems, the public is also asked about general perceptions of major global risks, obtaining an $18 \%$ of agree on the consideration of climate change as the most serious problem facing the world.

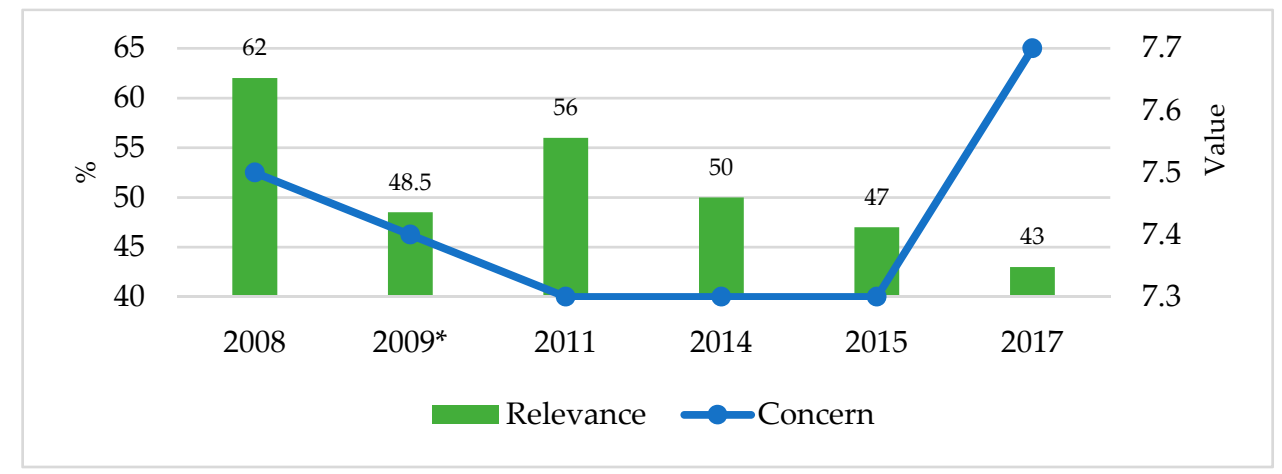

Figure 3. Relevance and concern about climate change as a serious problem. Note: ${ }^{*}$ The value obtained in 2009 corresponds to the average resulting from the two surveys conducted in January-February and August-September.

In addition, socio-demographic results indicate that in 2008, more males considered global warming to be a serious problem than women, and those who position themselves at the left end of the political scale. In 2011, those who are aged 20 or over considered climate change as the main challenge for future generations, while those who position themselves at the right-wing of the political scale and retired were not aware that climate change was a problem. In 2015 and 2017, data shows how those who finished education and are aged between 20 and 54 years old are more aware of climate change risk, and those who have taken personal action to fight climate change.

Question 2: Responsibility and action

This question is focused on asking if enough is done to fight climate change. An assessment of who the general public think is responsible for tackling climate change is conducted. Respondents were asked who they thought was responsible for tackling climate change, choosing as many responses as they wished from a list of options presented to them ${ }^{4}$. Since 2009, respondents are recognizing a change of tendency in giving responsibility for action to climate change (Figure 4). In the last ten years, responsibility has decreased for all agents but especially for regional and local authorities, and the public. Their relevance, in line with environmental groups, who have also received a low level of responsibility, may suggest (1) how climate change claims for an institutional action (co-led by the European Union and national governments), and (2) how the public put value in those actions carried out locally (for example, through the action promoted by environmental groups in recent years) as a way to check if those institutional policies promoted to deal with climate change are appropriate and efficient or not. Meanwhile, the temporary evolution of the survey also highlights how one in five respondents consider that responsibility for tackling climate change lies with all of the actors listed

4 The European Union; National Governments; Regional and local authorities; Corporations and industry; Environmental Groups; Citizens (the public); All of them. 
(although during the years 2011 and 2013 the percentage was significantly lower, 10\% in 2011 and $16 \%$ in 2013). Moreover, respondents recognize that fighting climate change will only be effective if all countries of the world act together.

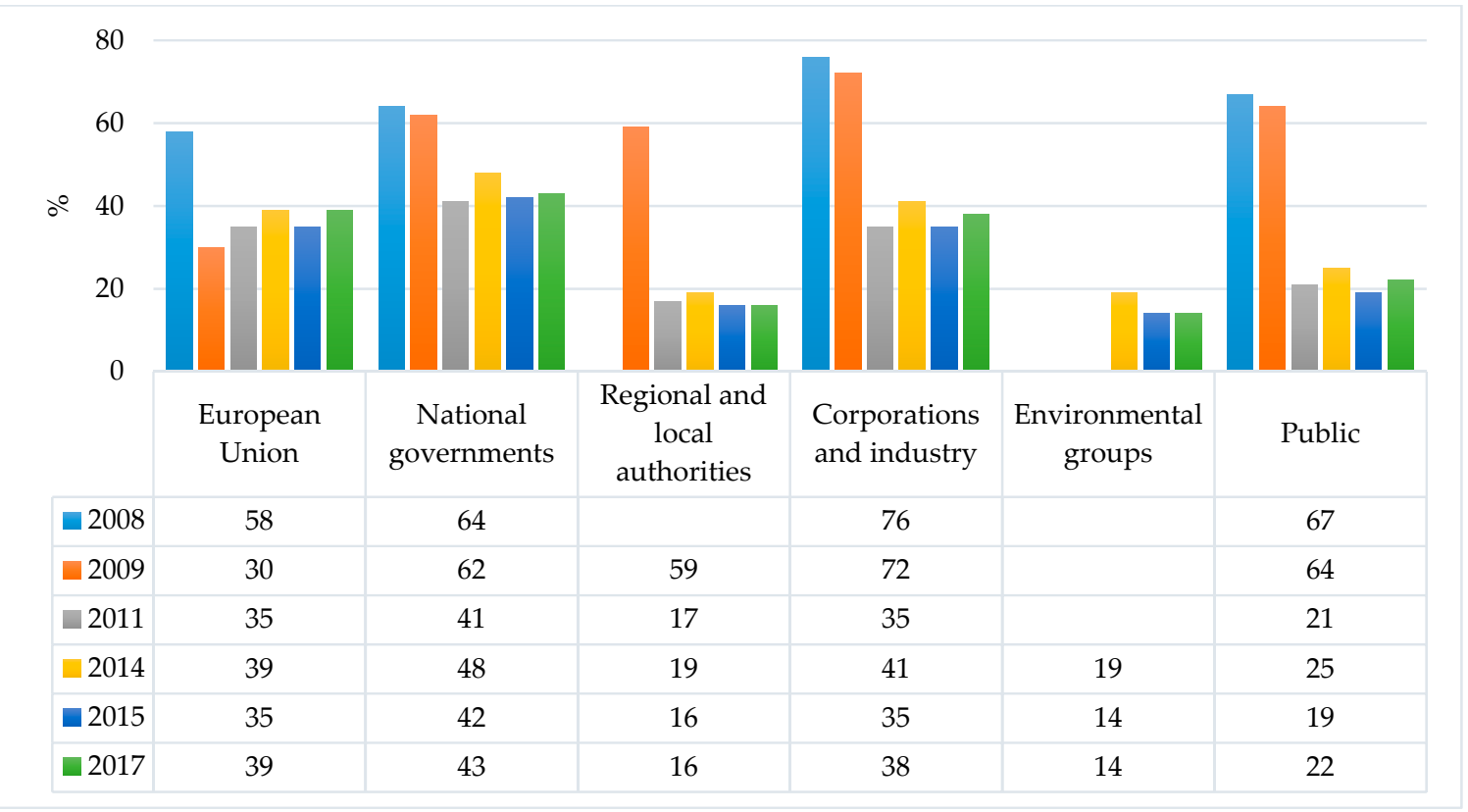

Figure 4. Responsibility to fight climate change. Note: * Only the survey conducted in August-September 2009 asked about responsibility on fighting climate change. ${ }^{* *}$ The 2008 survey did not include Regional and local authorities and Environmental groups as options, and 2009 and 2011 surveys only included Regional and local authorities as an option.

\subsubsection{Environment and Agriculture Reports}

Questions about how environmental and agricultural issues are in line with climate change concerns have been selected. Four reports focused on environmental issues include questions in which climate change is considered. Two main questions have also been selected:

Question 1: General associations with the environment

This question aims to identify the first association (from a list of predefined topics) with the term "environment". Respondents associate environmental pollution in towns and cities to climate change. Consequently, concern associated to environmental and climate change nexus has clearly increased in the last ten years: from 19\% (2008) to 51\% (2017). Furthermore, two of the main attributes traditionally associated to the environment were green landscapes and environmental protection, without receiving negative connotations.

Question 2: Main environmental concerns

The focus of this question was directly focused on identifying which type of environmental concerns ${ }^{5}$ are more recognized by society. On the previous question respondents consider that climate change is associated with the concept of environment, and therefore, it is not surprising that climate change is considered one of the main concerns among Europeans (57\% in 2008 and 51\% in 2017, but only $34 \%$ in 2011) mentioning it among their top five environmental concerns. Around two in five respondents also mention water and air pollution, and human disasters.

5 The 2015 report is focused on biodiversity and the question about environmental concerns has not been included. 
In addition, four Eurobarometer reports on agriculture and the CAP have also been considered. All of them include a special section (Section 4) focused on agriculture and climate change nexus. In this section, two main questions have been formulated.

Question 1: Helping farmers to fight climate change

A vast majority of respondents support the new objectives for agriculture and rural development included in the last reforms of the CAP, including the preservation of the countryside as a landscaping value and the conviction that farmers should receive support to face the consequences of climate change. In 2010 and 2014 reports, this percentage was around 80\% or more, while in 2016 and 2018 reports has decreased to 50\%. In 2016 report, the respondents with a strong political view, are more likely to think the benefit agriculture and rural landscape provide is contributing to fight climate change $(75 \%)$ than those with a low political view (66\%).

Question 2: Agriculture contribution in fighting climate change

About half of respondents ( $46 \%$ in 2010) and more than two-thirds of respondents (68\% in 2016) positively consider the proactive attitude of farmers in fighting climate change. However, current sustainable practices and adaptation measures promoted by farmers are not sufficient, and further action should be considered, including the option to change the way in which farmers work $(82 \%$ in 2014). This claim for a greater involvement of farmers in fighting climate change (77\% in 2014 and $65 \%$ in 2018) also aims to deal with those risks and impacts magnified by climate change and directly suffered by farmers. The results also suggest that almost one in three respondents in 2018 are ready to pay $10 \%$ more for agricultural products if these products have been produced under sustainable and climate change-limiting measures. Although this percentage has been decreased over time $(58 \%$ in 2010), the current result is in line with one of the transformative strategies proposed by the Impacts and risks rom high-end scenarios: Strategies for innovative solutions (IMPRESSIONS) project. This strategy was based on the promotion of climate friendly intensive agricultural practices in order to open its product to a more demanding but also more economically valuable food market. Such support is remarkable, considering that almost two thirds (61\% in 2010) of the respondents considered that agriculture is not one of the major causes of climate change but half of respondents ( $50 \%$ in 2018) consider tackling climate change should be the main responsibility of farmers, as well as the main objective for agricultural and rural policy.

\subsubsection{Research Projects}

Results from Eurobarometer reports have been contrasted with specific results obtained from selected EU research projects. Those projects selected from FP7 Environment program have included specific issues related to climate changes as promotion of action campaigns, identification of major risks, or asking for public strategies in order to address climate change. The Action on climate change through engagement, network and tools (ACCENT) project, for example, aimed to increase public mobilization when addressing climate change actions by ensuring the exchange and dissemination of good practices. One of the main dissemination activities was "The I Do campaign" as a mechanism for communicating the science of climate change in Europe. Accordingly, the messages clearly communicated were: (1) Climate change is happening and the effects are long-term; (2) Adaptation actions will mitigate climate change causes; and (3) There are risks to the "do-nothing" option. The study confirmed that people consider climate change as a serious problem that requires urgent actions (coinciding with what was expressed in the Eurobarometer reports on agriculture and environment). The public considers that the media (radio, TV and newspapers), movies and books pay little attention to global warming, and they would like more information on the global warming impacts on human health, and on what they can do to reduce global warming. Another important point is how information on climate change is presented: messages are intermittent, confused, alarmist and contradictory. Therefore, people have difficulty understanding an issue and making decisions. In fact, the information-action nexus is considered one of the main concerns when asking for climate change. According to this, the EPCC project aimed to identify the structure of climate change perception in different European countries 
(France, Germany, Norway and UK) by asking for the role of individual and contextual socio-political ${ }^{6}$ values. Two main questions have been selected according to these values.

Question 1: Images of climate change

Perception of climate change is mostly focused on the nature of the image associated with natural and anthropogenic impacts. Respondents considered that weather changes, including the weather becoming wetter, hotter, or simply more extreme and unpredictable, are the best form to be aware of the consequences of climate change.

Question 2: Climate change beliefs

This question includes three main topics: beliefs, feelings, and salvation. Beliefs about the level of awareness and main natural and anthropogenic causes of climate change are analyzed to measure trend skepticism. In order to achieve this goal, the project asked respondents whether they think climate change was happening or not. In all four countries, a majority of respondents (83-92\%) considered that the world's climate is changing, and this alteration is motivated and caused at least partly by human activity (83-91\%). However, this majority tends to differ according to the level of human responsibility in addressing climate change impacts. For example, about one in three and one-half of the respondents $(34-55 \%)$ considered human activity as the main or the exclusive cause of climate change, while a similar percentage (34-57\%) considered that climate change is caused by the combination of natural processes and human activities. Psychological distance of climate change (as understood as feelings towards climate change) has been analyzed and a majority in all four countries (60-61\%) consider that the effects of climate change are already identified and perceived by the whole society depending on space and time. On the contrary, only $2-5 \%$ of the respondents answered that they would start feeling the effects of climate change in the next 100 years or beyond. Finally, respondents are asked about the role of science in providing solutions to address climate change impacts. This question is in line with those technical approaches in which science, innovation and technology are conceived to fight complex environmental problems, such as climate change. The obtained results in France and Germany show how people were skeptical that science and technology would eventually solve their problems with climate change ( $46 \%$ and $38 \%$ respectively). The situation is inverse in Norway and UK, in which more than half of the respondents (56\%) and four in ten of the respondents $(40 \%)$ respectively trust in technological advances and innovation to fight climate change. A synthesis of the main issues considered by farmers when explaining their perception on climate change risks and challenges are detailed in Figure 5. The public considered that questions about scientific prestige and political agreements are positive issues when addressing climate change, while uncertainty from experts, skepticism and short-term solutions, and populism are limiting the adaptation to climate change scenarios.

6 National analysis about the socio-political profile of each country provides two main key issues. On the one hand, France and Germany counts with a national government which develops and applies adaptation policies at regional level; NGO and civil society organization are represented in state consultative bodies for discussing measures to mitigate climate change; and very small fringe of scientists who deny climate change. In the opposite site, Norway and France present a cognitive dissonance: for example, Norway seeks a climate-friendly image at home and abroad, while being unable to curb its domestic emissions and maintaining fossil fuel exports at relatively high levels. In UK, political sector has a history of framing nuclear power as a solution to climate change, while public perception research identifies a consistent preference for renewable energy. 

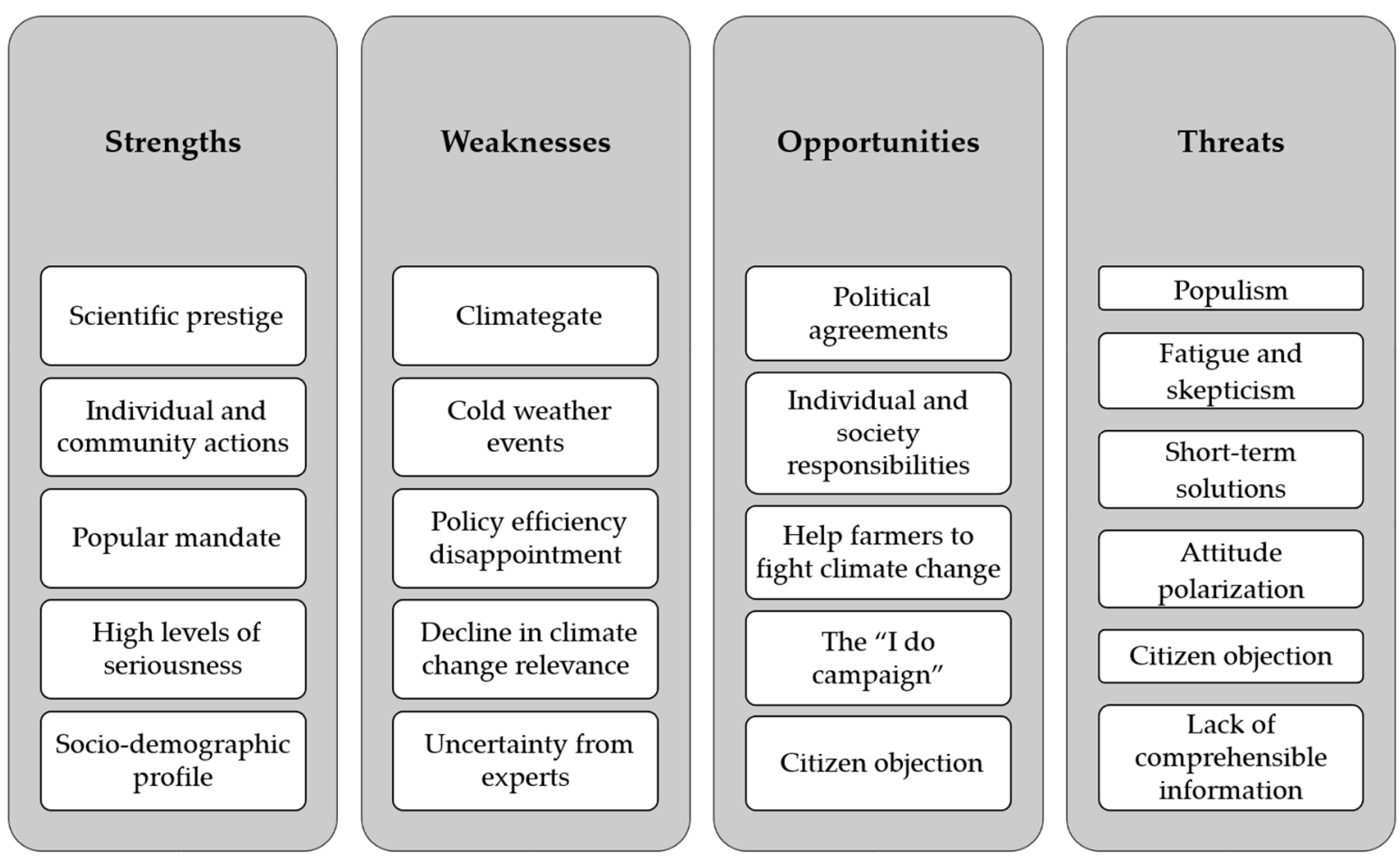

Figure 5. SWOT analysis including the main issues considered by the public when addressing climate change perceptions. (Source: Own elaboration from Eurobarometer reports and research projects.)

\section{Discussion}

Are the farmers aware of climate change and the associated risks? What are the factors that influence this awareness and farmers' perceptions? How will they adapt? Is the public aware of the climate risk faced by farmers? Is climate change one of the main environmental concerns cited by the public? How the public perceives farmers' role in fighting climate change? Some of these questions have been addressed in the previous sections by confronting public and farmers' attitudes and climate change perception. According to Torabi et al. [101], awareness occurs as both the public and farmers learn through their social networks (including friends, family, and neighbors) but also from personal experience. However, questions about the role of the media and its ability to generate opinion and promote debate that will be subsequently incorporated into the speeches of both the public and farmers are also relevant although they are not included in the literature, opinion surveys or research projects duly analyzed. In fact, both farmers and the public are indirectly aware of the role played by the media through opinion and blog sections or science-based editorials [102]. Research conducted by Gavin and Marshall [103] suggests that trust in entities that are working to address climate change is associated with support for climate change policy, while trust in private services (i.e., industry) and the media historically opposed to action on climate change is associated with skepticism and inaction to address climate change impacts. The question posed by this duality is how to address climate change perception by considering technical, political and societal changes and media interests.

Ahead of the global climate conference COP24, the European Investment Bank launched a first-of-its-kind climate survey, in partnership with the global public opinion company YouGov, to find out how 25,000 citizens feel towards climate change in the European Union, the United States and China. First key findings show the public sentiment towards climate change in the European Union. These highlight a geographical disparity between the North and the South. Southern Europeans are particularly concerned about the impacts of climate change and see it much more as an immediate threat. They also believe it is mostly caused by human activities. On the contrary, northern Europeans are less worried about climate change and less convinced of the impact of human activities. Although the survey does not provide sociodemographic profiles of the respondents, uncertainty, coupled with 
skepticism, is identified as a common finding when asking about sentiments on climate change. Our analysis is in line with this statement as climate change has a domino effect on both farmers and the public, often starting with a concerned sentiment towards direct or indirect impacts on environmental, agricultural, economic and social domains [104,105]. The survey also reflects how experiencing physical manifestations of climate change at regional scale contribute to farmers' adaptation, while scientific uncertainties and political incomprehension limit the social concern and the need to act [106]. Our analysis from Eurobarometer and research projects have also proved that personal experience of climate change is interdependent with the belief that climate change is happening. What is noticeable from this result is that the greater the years of farmers' farming experiences the greater the percentage rate of their climate change awareness. This contrasts with the attitude of the public according to the Eurobarometer reports, in which climate change generates fatigue in older generations while brings back the consciousness of the youngest and drives adaptation measures. However, one of the main limitations of both sources is that they are unable to deepen into why society and farmers are aware and are concerned about climate change, focusing merely on statements or denials of specific postulates and perceived ambiguity [107].

An interesting exercise to overcome this limitation is to compare farmers and the public perceptions about which issues can be positively or negatively considered when addressing climate change. Both farmers and the public coincide in highlighting scientific consensus and prestige as key strengths to fighting climate change, although farmers also emphasize the role of technology (technosalvation) and the public accentuates the role of the popular mandate. However, a major challenge for raising awareness of climate change and motivating active adaptation measures is the dissemination of scientific information in terms that are understandable to the layman: that is, anyone without scientific training, including many decision makers [108]. Moreover, both social groups also agree to identify knowledge gaps or scientific uncertainty from experts, and political incomprehension as main weaknesses, even though farmers insist on the role of the media and the public urges to put attention to climate extreme events in order to understand climate change challenges. Although political incomprehension is considered a weakness by farmers and the public, both of them trust in political will as the most effective way to reach agreements between confronted interests. Nonetheless, both farmers and the public differ in how they press politicians to encourage climate change corrective actions. On the one hand, farmers put the focus on previous experience in managing climate change risks as a mechanism to persuade politicians about best adaptation measures. Contrarily, the public aims to promote individual and societal responsibilities by taking advantage of local knowledge and social-learning approaches. In fact, both strategies are unequivocally promoted by farmers and the public as mechanisms to face skepticism, reduce meteorological risks and to overcome short-term solutions.

Adaptation can be constrained not only by technical difficulties or scientific disagreements, but also for the absence of political will and consensus, opposed cultural factors, lack of governance, confronted strategies, debated worldviews, discussed norms or incomprehensible behaviors. Among all these limiting factors, both farmers and the public coincide in highlighting how climate change has become a political contrivance [109,110]. According to Wolf et al. [111] social and cultural values on climate change adaptation can play a key role when analyzing the perception of risk, what type of action could be addressed according to usefulness, or how vulnerability and resilience would be included in the management of natural and human activities. Consequently, a significant need to develop innovative methods able to increase social-learning and promote comprehensible climate information in line with farmers and the public attitudes and demands is needed [112]. For example, if national policies support climate change measures duly implemented by farmers based on their local knowledge and experience as a bottom-up approach, their adaptation capacity will increase and their activity will be less vulnerable to climate change effects [113-115]. Moreover, the promotion of policy game decision support mechanisms could play an extremely significant role in instigating policy action to support the implementation of adaptation measures by the public, bridging the familiarity gap 
with stories and metaphors, as demonstrated in Onencan and Van de Walle research [116]. Another method for awareness-raising is the Climate Twins approach, duly applied in urban context in order to illustrate the amplitude and celerity of climate change but also in rural context to determine climate change impacts on agriculture and their associated adaptation options [117]. In both contexts, this method could be used as a communication tool to raise the population's awareness about the expected impacts of climate change. Likewise, adaptive capacity can be limited by the inconsistency between meteorological records and communication of public and farmers' observations and perceptions [118]. In fact, the perception of both farmers and the public is separately formulated from scientists: whereas scientists make highly global assessments by considering few common variables applied to specific case studies in order to extrapolate conclusions to other places, farmers and the public perceive climatic trends based on their assessment of the frequency and intensity of climate data at local scale. However, the public tends to put attention to climatic data obtained by scientists more than focus their attention to farmers' experience.

Climate change adaptation and mitigation measures are in line with the terms 'responsibility' and 'action'. The results obtained from the Eurobarometer analysis show how although so many people are concerned about climate change, environmental issues, food security, and sustainability, more of them not doing what is necessary to address these challenges. Some observers suggest that this is motivated by a climate change denier-believer debate in which politics could defend skepticism as a mechanism to reject climate science [119]. In a number of societies, views about climate change divide sharply along partisan lines. As it can be extracted from the EPCC project, in different economically advanced nations, such as France, Germany and the UK, those on the political left are significantly more likely than those on the right to view climate change as a major threat. Gifford [120] and Lacroix and Gifford [121] suggest that politicians tend to use different psychological barriers as factors able to limit climate change behavior change (ensuring populism). Four of these barriers can be applied when analyzing farmers and public climate change perception: (1) Ignorance (not knowing that a problem exists and/or not knowing what to do once one becomes aware of the problem); (2) Undervaluing future risks (spatial discounting of environmental problems); (3) Perceived behavioral control and self-efficacy (people do not act because their actions will not have much impact), and (4) Technosalvation (support geoengineering as a tool in the struggle against further global warming). According to our analysis, the public tends to include the first two barriers when they want to justify their inaction and the politicians' role, while the second two are justified by farmers in order to be more resilient at local level and pressure the politicians to adopt actions to redress the effects of climate change on agriculture.

\section{Conclusions}

Climate change is more complex than any other environmental problem. Agricultural practices are exposed to multiple, simultaneous and interconnected ecological, economic and social pressures motivated by climate change. According to this, agriculture is also growing in prominence within the political agendas of national and international agencies, in which debates about how to feed a growing global population under increasing constraints of water and land resources scarcity and climate change impacts are frequent. Information about climate change is disseminated using different platforms and formats, from technical issues and reports to research projects, and from survey opinions to the media. However, information is unlikely to be clearly assimilated because public and farmers' perception is not neutral: while the evidence for anthropogenic climate change grows stronger, uncertainty remains on the social, economic, moral and political aspects of climate change.

Climate change is not viewed as a distant threat. Across the literature review and surveys, more attention has been paid to meteorological data and modelling, climate change impacts, and adaptation and risk assessment, but relatively little attention has been devoted to the perception and awareness of farmers and the public when adapting to climate change. What is apparent is the gap between politicians' discourses, scientists' analysis, farmers' awareness, and public' beliefs 
of climate change. For example, differences among farmers and public perceptions were noted. Uncertainty, coupled with skepticism, the media, and political will, are common findings when asking to farmers and the public for the main weaknesses in adaptation to climate change. However, scientific consensus, meteorological data and projections, barriers to adaptation, and the positive role of technology (nicknamed "technosalvation" for its ability to cope with climate change risks) are subjects in which both differ. This is partly explained by the fact that (1) confronting climate change will require significant changes in the public and farmers' lifestyles, and (2) views about climate change break sharply along partisan, gender and generational lines. Both issues could be merge if local knowledge is integrated into climate change policies and actions as a mechanism to increase legitimacy of the decision-making process, especially when evaluating farmers and the public perception. On one hand, it helps to give policy more consistency and steadiness into agricultural practices that attempt to bring about reshaping cropping calendars or fighting rainfall variability at local levels. On the other hand, it promotes public comprehension about farmers' role and attitudes towards climate change adaptation. This may demand that adaptation interventions search for solutions together with farmers and public rather than prescribing solutions misunderstood by the public.

Examining the perceived importance of climate change impacts and differences in knowledgebase among farmers will help researchers, politicians, and policy makers delineate effective measures and mechanisms, which could ultimately reveal new and potentially beneficial insights into farmers' attitude changes. Much of the current research depends on (1) how farmers perceive climate change impacts and how they face the challenges in order to ensure its activity, and (2) how the public value the role of the farmer in addressing climate change. However, both approaches are rarely linked in a direct way, and there is no clear feedback between farmers and public actions. Future research needs to put a greater focus on how the public and farmers perceive climate change through a joint analysis, taking advantage of some of the tools and approaches provided in the literature in which confronted values, behaviors and attitudes about climate change include real-world viewpoints (local experience and knowledge) and scientific results (meteorological data and projections). In order to succeed in this task, it would be useful to support cross-cultural research in anthropology, sociology, geography, and other fields on the issue of climate change to deepen understanding contextual (scientific) and cultural (social-learning) factors that influence individual and group attitudinal and behavioral outcomes.

Funding: This research was funded by the Spanish Ministry of Science, Innovation and Universities, grant number FJCI-2015-24346.

Conflicts of Interest: The authors declare no conflict of interest.

\section{References}

1. Findlater, K.M.; Satterfield, T.; Kandlikar, M.; Donner, D.D. Six languages for a risky climate: How farmers react to weather and climate change. Clim. Chang. 2018, 148, 451-465. [CrossRef]

2. Merino-Saum, A.; Baldi, M.G.; Gunderson, I.; Oberle, B. Articulating natural resources and sustainable development goals through green economy indicators: A systematic analysis. Resour. Conserv. Recycl. 2018, 139, 90-103. [CrossRef]

3. Gil Olcina, A.; Olcina Cantos, J. Tratado de Climatología; Publicaciones de la Universidad de Alicante: Alicante, Spain, 2017; 949p, ISBN 978-84-9717-519-7.

4. Gori, A.; Brito, C.B.; Ruiz, J. Climate change and agriculture: Do environmental preservation and ecosystem services matter? Ecol. Econ. 2018, 152, 27-39. [CrossRef]

5. Jiménez Cisneros, B.E.; Oki, T.; Arnell, N.W.; Benito, G.; Cogley, J.G.; Döll, P.; Jiang, T.; Mwakalila, S.S. Freshwater resources. In Climate Change 2014: Impacts, Adaptation, and Vulnerability. Part A: Global and Sectoral Aspects; Contribution of Working Group II to the Fifth Assessment Report of the Intergovernmental Panel on Climate Change; Cambridge University Press: Cambridge, UK; New York, NY, USA, 2014; pp. $229-269$.

6. Konzmann, M.; Gerten, D.; Heinke, J. Climate impacts on global irrigation requirements under 19 GCMs, simulated with a vegetation and hydrology model. Hydrol. Sci. J. 2013, 58, 1-18. [CrossRef] 
7. Dinesh, D.; Zougmore, R.B.; Vervoort, J.; Totin, E.; Thornton, P.K.; Solomon, D.; Shirsath, P.B.; Pede, V.O.; Lopez Noriega, I.; Läderach, P.; et al. Facilitating change for climate-smart agriculture through science-policy engagement. Sustainability 2018, 10, 2616. [CrossRef]

8. Porter, J.R.; Xie, L.; Challinor, A.J.; Cochrane, K.; Howden, S.M.; Iqbal, M.M.; Lobell, D.B.; Travasso, M.I. Food security and food production systems. In Climate Change 2014: Impacts, Adaptation, and Vulnerability. Part A: Global and Sectoral Aspects. Contribution of Working Group II to the Fifth Assessment Report of the Intergovernmental Panel on Climate Change; Field, C.B., Barros, V.R., Dokken, D.J., Mach, K.J., Mastrandrea, M.D., Bilir, T.E., Chatterjee, M., Ebi, K.L., Estrada, Y.O., Genova, R.C., et al., Eds.; Cambridge University Press: Cambridge, UK; New York, NY, USA, 2014; pp. 485-533.

9. De Vrese, P.; Stacke, T.; Hagemann, S. Exploring the biogeophysical limits of global food production under different climate change scenarios. Earth Syst. Dyn. 2018, 9, 393-412. [CrossRef]

10. Chiles, R.M.; Fabian, E.E.; Tobin, D.; Colby, S.J.; DePue, S.M. Greenhouse gas emissions from agriculture: Reconciling the epistemological, ethical, political, and practical challenges. J. Agric. Environ. Ethics 2018, 31, 341-348. [CrossRef]

11. Fellmann, T.; Witzke, P.; Weiss, F.; Van Doorslaer, B.; Drabik, D.; Huck, I.; Salputra, G.; Jansson, T.; Leip, A. Major challenges of integrating agriculture into climate change mitigation policy frameworks. Mitig. Adapt. Strat. Glob. Chang. 2018, 23, 451-468. [CrossRef]

12. IPCC. Climate change 2014: Synthesis report. In Contribution of Working Groups I, II and III to the Fifth Assessment Report of the Intergovernmental Panel on Climate Change; IPCC: Geneva, Switzerland, 2014; ISBN 978-92-9169-142-5.

13. Yawson, D.O.; Mulholland, B.J.; Ball, T.; Adu, M.O.; Mohan, S.; White, P.J. Effect of climate change and agricultural land use changes on UK feed barley production and food security to the 2050s. Land 2017, 6, 74. [CrossRef]

14. Blanco, M.; Ramos, F.; van Doorslaer, B.; Martínez, P.; Fumagalli, D.; Ceglar, A.; Fernández, F.J. Climate change impacts on EU agriculture: A regionalized perspective taking into account market-driven adjustments. Agric. Syst. 2017, 156, 52-66. [CrossRef]

15. Iglesias, A.; Quiroga, S.; Moneo, M.; Garrote, L. From climate change impacts to the development of adaptation strategies: Challenges for agriculture in Europe. Clim. Chang. 2012, 112, 143-168. [CrossRef]

16. Wang, J.; Vanga, S.K.; Saxena, R.; Orsat, V.; Raghavan, V. Effect of climate change on the yield of cereal crops: A review. Climate 2018, 6, 41. [CrossRef]

17. García-Ruiz, J.M.; López-Moreno, J.I.; Vicente-Serrano, S.M.; Lasanta-Martínez, T.; Baguería, S. Mediterranean water resources in a global change scenario. Earth-Sci. Rev. 2011, 105, 121-139. [CrossRef]

18. Iglesias, A.; Garrote, L. Adaptation strategies for agricultural water management under climate change in Europe. Agric. Water Manag. 2015, 155, 113-124. [CrossRef]

19. Dankers, R.; Feyen, L. Climate change impact on flood hazard in Europe: An assessment based on high-resolution climate simulations. J. Geophys. Res. 2008, 113, D19105. [CrossRef]

20. Kovats, R.S.; Valentini, R.; Bouwer, L.M.; Georgopoulou, E.; Jacob, D.; Martin, E.; Rounsevell, M.; Soussana, J.F. Europe. In Climate Change 2014: Impacts, Adaptation, and Vulnerability. Part B: Regional Aspects. Contribution of Working Group II to the Fifth Assessment Report of the Intergovernmental Panel on Climate Change; Barros, V.R., Field, C.B., Dokken, D.J., Mastrandrea, M.D., Mach, K.J., Bilir, T.E., Chatterjee, M., Ebi, K.L., Estrada, Y.O., Genova, R.C., et al., Eds.; Cambridge University Press: Cambridge, UK; New York, NY, USA, 2014; pp. 1267-1326.

21. Ndamani, F.; Watanabe, T. Determinants of farmers' climate risk perceptions in agriculture-A rural Ghana perspective. Water 2017, 9, 210. [CrossRef]

22. Ricart, $\mathrm{S}$. Water management and irrigation governance in the Anthropocene: Moving from physical solutions to social involvement. J. Geogr. Environ. Earth Sci. Int. 2018, 15, 1-15. [CrossRef]

23. Shwom, R.; Bidwell, D.; Dan, A.; Dietz, T. Understanding US public support for domestic climate change policies. Glob. Environ. Chang. Hum. Policy Dimens. 2010, 20, 472-482. [CrossRef]

24. Lebel, P.; Whangchai, N.; Chitmanat, C.; Promya, J.; Lebel, L. Perceptions of climate related risks and awareness of climate change of fish cage farmers in northern Thailand. Risk Manag. 2015, 17, 1-22. [CrossRef]

25. Abid, M.; Schilling, J.; Scheffran, J.; Zulfiqar, F. Climate change vulnerability, adaptation and risk perceptions at farm level in Punjab, Pakistan. Sci. Total Environ. 2016, 547, 447-460. [CrossRef] 
26. Howley, P.; Yadav, L.; Hynes, S.; Donoghue, C.O.; Neill, S.O. Contrasting the attitudes of farmers and the general public regarding the 'multifunctional' role of the agricultural sector. Land Use Policy 2014, 38, 248-256. [CrossRef]

27. Marquart-Pyatt, S.; McCright, A.M.; Dietz, T.; Dunlap, R.E. Politics eclipse climate extremes for climate change perceptions. Glob. Environ. Chang. 2014, 29, 246-257. [CrossRef]

28. Lucas, C.H. Concerning values: What underlies public polarisation about climate change? Geogr. Res. 2018, 56, 298-310. [CrossRef]

29. McCright, A.M.; Dunlap, R.E.; Marquart-Pyatt, S.T. Political ideology and views about climate change in the European Union. Environ. Politics 2016, 25, 338-358. [CrossRef]

30. Lockwood, M. Right-wing populism and the climate change agenda: Exploring linkages. Environ. Politics 2018, 27, 712-732. [CrossRef]

31. Jäger, A. The Semantic Drift: Images of Populism in Post-War American Historiography and Their Relevance for (European) Political Science; Working Paper 3; Populismus: Thessaloniki, Greece, 2016. Available online: http:/ / www.populismus.gr/wp-content/uploads/2016/07/WP3-jaeger-final-upload.pdf (accessed on 19 September 2018).

32. Lewandowsky, S. Conspiratory fascination versus public interest: The case of the 'climategate'. Environ. Res. Lett. 2014, 9, 111004. [CrossRef]

33. Dunn, M.; Rounsevell, M.D.; Carlsen, H.; Dzebo, A.; Capela, T.; Hagg, J. To what extent are land resource managers preparing for high-end climate change in Scotland? Clim. Chang. 2017, 141, 181-195. [CrossRef]

34. Adger, W.N.; Dessai, S.; Goulden, M.; Hulme, M.; Lorenzoni, I.; Nelson, D.R.; Naess, L.O.; Wolf, J.; Wreford, A. Are there social limits to adaptation to climate change? Clim. Chang. 2009, 93, 335-354. [CrossRef]

35. Newman, T.P.; Nisbet, E.C.; Nisbet, M.C. Climate change, cultural cognition, and media effects: Worldviews drive news selectivity, biased processing, and polarized attitudes. Public Underst. Sci. 2018, 27, 985-1002. [CrossRef]

36. Porter, A.J.; Hellsten, I. Investigating participatory dynamics through social media using a multideterminant "frame" approach: The case of climategate on YouTube. J. Comput. Mediat. Commun. 2014, 19, 1024-1041. [CrossRef]

37. McCright, A.M.; Dunlap, R.E. Cool dudes: The denial of climate change among conservative white males in the United States. Glob. Environ. Chang. 2011, 21, 1163-1172. [CrossRef]

38. Cook, J.; Nuccitelli, D.; Green, S.; Richardson, M.; Winkler, B.; Painting, R.; Way, R.; Jacobs, P.; Skuce, A. Quantifying the consensus on anthropogenic global warming in the scientific literature. Environ. Res. Lett. 2013, 8, 024024. [CrossRef]

39. Adimassu, Z.; Kessler, A. Factors affecting farmers' coping and adaptation strategies to perceived trends of declining rainfall and crop productivity in the central Rift valley of Ethiopia. Environ. Syst. Res. 2016, 5, 13. [CrossRef]

40. Ayanlade, A.; Radeny, M.; Morton, J.F. Comparing smallholder farmers' perception of climate change with meteorological data: A case study from southwestern Nigeria. Weather Clim. Extrem. 2017, 15, 24-33. [CrossRef]

41. Hulme, M.; Obermeister, N.; Randalls, S.; Borie, M. Framing the challenge of climate change in Nature and Science editorials. Nat. Clim. Chang. 2018, 8, 515-521. [CrossRef]

42. Kukkonen, A.; Ylä-Anttila, T.; Swarnakar, P.; Broadbent, J.; Lahsen, M.; Stoddart, M.C.J. International organizations, advocacy coalitions, and domestication of global norms: Debates on climate change in Canada, the US, Brazil, and India. Environ. Sci. Policy 2018, 81, 54-62. [CrossRef]

43. Falagas, M.; Pitsouni, E.; Malietzis, G.; Pappas, G. Comparison of PubMed, Scopus, Web of Science, and Google Scholar: Strengths and Weaknesses. FASEB J. 2008, 22, 338-342. [CrossRef] [PubMed]

44. Flávio, H.M.; Ferreira, P.; Formigo, N.; Svendsen, J.C. Reconciling agriculture and stream restoration in Europe: A review relating to the EU Water Framework Directive. Sci. Total Environ. 2017, 596-597, 378-395. [CrossRef]

45. Pearce, T.D.; Rodríguez, E.H.; Fawcett, D.; Ford, J.D. How is Australia adapting to climate change based on systematic review? Sustainability 2018, 10, 3280. [CrossRef]

46. Nissen, S. The Eurobarometer and the process of European integration. Qual. Quant. 2014, 48, 713-727. [CrossRef] 
47. Oztig, L.L. Europe's climate change policies: The Paris Agreement and beyond. Energy Sources Part B Econ. Plan. Policy 2017, 12, 917-924. [CrossRef]

48. Olayide, O.E.; Alabi, T. Between rainfall and food poverty: Assessing vulnerability to climate change in agricultural economy. J. Clean. Prod. 2018, 198, 1-10. [CrossRef]

49. Dolan, P.; Hallsworth, M.; Halpern, D.; King, D.; Metcalfe, R.; Vlaev, I. Influencing behaviour: The mindspace way. J. Econ. Psychol. 2012, 33, 264-277. [CrossRef]

50. Scruggs, L.; Benegal, S. Declining public concern about climate change: Can we blame the great recession? Glob. Environ. Chang. 2012, 22, 505-515. [CrossRef]

51. Reyes-García, V.; Fernández-Llamazares, A.; Guèze, M.; Garcés, A.; Mallo, M.; Vila-Gómez, M.; Vilaseca, M. Local indicators of climate change: The potential contribution of local knowledge to climate research. Wires Clim. Chang. 2016, 7, 109-124. [CrossRef] [PubMed]

52. Lee, T.N.; Markowitz, E.M.; Howe, P.D.; Ko, C.-Y.; Leiserowitz, A.A. Predictors of public climate change awareness and risk perception around the world. Nat. Clim. Chang. 2015, 5, 1014-1024. [CrossRef]

53. Whitmarsh, L. Scepticism and uncertainty about climate change: Dimensions, determinants and change over time. Glob. Environ. Chang. 2011, 21, 690-700. [CrossRef]

54. O'Neill, S.; Nicholson-Cole, S. 'Fear won't do it': Promoting positive engagement with climate change through visual and iconic representations. Sci. Commun. 2009, 30, 355-379. [CrossRef]

55. Nisbet, E.C.; Myers, T. The polls-Trends twenty years of public opinion about global warming. Public Opin. Q. 2007, 71, 444-470. [CrossRef]

56. Kachi, A.; Bernauer, T.; Gampfer, R. Climate policy in hard times: Are the pessimists right? Ecol. Econ. 2015, 114, 227-241. [CrossRef]

57. Chingala, G.; Mapiye, C.; Raffrenato, E.; Hoffman, L.; Dzama, K. Determinants of smallholder' farmers perceptions of impact of climate change on beef production in Malawi. Clim. Chang. 2017, 142, 129-142. [CrossRef]

58. Greenhill, M.; Leviston, Z.; Leonard, R.; Walker, I. Assessing climate change beliefs: Response effects of question wording and response alternatives. Public Underst. Sci. 2014, 23, 947-965. [CrossRef]

59. Barnes, A.P.; Toma, L. A typology of dairy farmer perceptions towards climate change. Clim. Chang. 2012, 112, 507-522. [CrossRef]

60. Gordon, J.; Wright, L.; Hobbs, J. Understanding farmer perspectives on climate change adaptation and mitigation: The roles of trust in sources of climate information, climate change beliefs, and perceived risks. Environ. Behav. 2015, 47, 205-234. [CrossRef]

61. Menapace, L.; Colson, G.; Raffaelli, R. Climate change beliefs and perceptions of agricultural risks: An application of the exchangeability method. Glob. Environ. Chang. 2015, 35, 70-81. [CrossRef]

62. Nguyen, T.; Seddaiu, G.; Virdis, S.; Tidore, C.; Pasqui, M.; Roggero, P.P. Perceiving to learn or learning to perceive? Understanding farmers' perceptions and adaptation to climate uncertainties. Agric. Syst. 2016, 143, 205-216. [CrossRef]

63. Woods, B.A.; Nielsen, H.O.; Pedersen, A.B.; Kristofersson, D. Farmers' perceptions of climate change and their likely responses in Danish agriculture. Land Use Policy 2017, 65, 109-120. [CrossRef]

64. Barkmann, T.; Siebert, R.; Lange, A. Land-use experts' perception of regional climate change: An empirical analysis from the North German Plain. Clim. Chang. 2017, 144, 287-301. [CrossRef]

65. Hatfield, J.L.; Prueger, J.H. Temperature extremes: Effect on plant growth and development. Weather Clim. Extrem. 2015, 10 Pt A, 4-10. [CrossRef]

66. Dhanya, P.; Ramachandran, A. Farmers' perceptions of climate change and the proposed agriculture adaptation strategies in a semi arid region of south India. J. Integr. Environ. Sci. 2016, 13, 1-18. [CrossRef]

67. Galdies, C.; Said, A.; Camilleri, L.; Caruana, M. Climate change trends in Malta and related beliefs, concerns, and attitudes toward adaptation among Gozitan farmers. Eur. J. Agron. 2016, 74, 18-28. [CrossRef]

68. Haden, V.R.; Niles, M.T.; Lubell, M.; Perlman, J.; Jackson, L.E. Global and local concerns: What attitudes and beliefs motivate farmers to mitigate and adapt to climate change? PLoS ONE 2012, 7, e52882. [CrossRef] [PubMed]

69. Deligios, P.A.; Chergia, A.P.; Sanna, G.; Solinas, S.; Todde, G.; Narvarte, L.; Ledda, L. Climate change adaptation and water saving by innovative irrigation management applied on open field globe artichoke. Sci. Total Environ. 2019, 649, 461-472. [CrossRef] [PubMed] 
70. Drummond, A.; Hall, L.C.; Sauer, J.D.; Palmer, M.A. Is public awareness and perceived threat of climate change associated with governmental mitigation targets? Clim. Chang. 2018, 149, 159-171. [CrossRef]

71. Li, S.; Juhász-Horváth, L.; Harrison, P.A.; Pintér, L.; Rounsevell, M.D.A. Relating farmers' perceptions of climate change risk to adaptation behaviuor in Hungary. J. Environ. Manag. 2017, 185, 21-30. [CrossRef] [PubMed]

72. Niles, M.T.; Mueller, N.D. Farmer perceptions of climate change: Associations with observed temperature and precipitation trends, irrigation, and climate beliefs. Glob. Environ. Chang. 2016, 39, 133-142. [CrossRef]

73. Habtemariam, L.T.; Gandorfer, M.; Kassa, G.A.; Heissenhuber, A. Factors influencing smallholder farmers' climate change perceptions: A study from farmers in Ethiopia. Environ. Manag. 2016, 58, 343-358. [CrossRef] [PubMed]

74. Hyland, J.; Jones, D.L.; Parkhill, K.A.; Barnes, A.P.; Williams, A.P. Farmers' perception of climate change: Identifying types. Agric. Hum. Values 2016, 33, 323-339. [CrossRef]

75. Lo, A.Y. The right to doubt: Climate change scepticism and asserted rights to private property. Environ. Politics 2014, 23, 549-569. [CrossRef]

76. Islam, M.M.; Barnes, A.; Toma, L. An investigation into climate change scepticism among farmers. J. Environ. Psychol. 2013, 34, 137-150. [CrossRef]

77. Hitayezu, P.; Wale, E.; Ortmann, G. Assessing farmers' perceptions about climate change: A double-hurdle-approach. Clim. Risk Manag. 2017, 17, 123-138. [CrossRef]

78. Hulme, M. Why We Disagree about Climate Change: Understanding Controversy, Inaction and Opportunity; Cambridge University Press: Cambridge, UK, 2009.

79. Corner, A.; Whitmarsh, L.; Xenias, D. Uncertainty, scepticism and attitudes towards climate change: Biased assimilation and attitude polarization. Clim. Chang. 2012, 114, 463-478. [CrossRef]

80. Häkkinen, K.; Akrami, N. Ideology and climate change denial. Personal. Individ. Differ. 2014, 70, 62-65. [CrossRef]

81. Hamilton, L.C.; Hartter, J.; Lemcke-Stampone, M.; Moore, D.W.; Safford, T.G. Tracking public beliefs about anthropogenic climate change. PLoS ONE 2015, 10, e0138208. [CrossRef] [PubMed]

82. Abid, M.; Scheffran, J.; Schneider, U.A.; Ashfaq, M. Farmers' perception of and adaptation strategies to climate change and their determinants: The case of Punjab province, Pakistan. Earth Syst. Dyn. 2015, 6, 225-243. [CrossRef]

83. Niles, M.T.; Brown, M.; Dynes, R. Farmers' intended and actual adoption of climate change mitigation and adaptation strategies. Clim. Chang. 2016, 135, 277-295. [CrossRef]

84. Leclère, D.; Jayet, P.-A.; de Noblet-Docoudré, N. Farm-level autonomous adaptation of European agricultural supply to climate change. Ecol. Econ. 2013, 87, 1-14. [CrossRef]

85. Asplund, T. Natural versus anthropogenic climate change: Swedish farmers' joint construction of climate perceptions. Public Underst. Sci. 2016, 25, 560-575. [CrossRef]

86. Prokopy, L.S.; Arbuckle, J.G.; Barnes, A.P.; Haden, V.R.; Hogan, A.; Niles, M.T.; Tyndall, J. Farmers and climate change: A cross-national comparison of beliefs and risk perceptions in high-income countries. Environ. Manag. 2015, 56, 492-504. [CrossRef]

87. Ochieng, J.; Kirimi, L.; Makau, J. Adapting to climate change variability and change in rural Kenya: Farmer perceptions, strategies and climate trend. Nat. Resour. Forum 2017, 41, 195-208. [CrossRef]

88. Kibue, G.W.; Liu, X.; Zheng, J.; Zhang, X.; Pan, G.; Li, L.; Han, X. Farmers' perception of climate variability and factors influencing adaptation: Evidence from Anhui and Jiangsu, China. Environ. Manag. 2016, 57, 976-986. [CrossRef] [PubMed]

89. Falloon, P.; Betts, R. Climate impacts on European agriculture and water management in the context of adaptation and mitigation-The importance of an integrated approach. Sci. Total Environ. 2010, 408, 5667-5687. [CrossRef]

90. Unsworth, K.L.; Fielding, K.S. It's political: How the salience of one's political identity changes climate change beliefs and policy support. Glob. Environ. Chang. 2014, 27, 131-137. [CrossRef]

91. Van Prooijen, A.-M.; Sparks, P. Attenuating initial beliefs: Increasing the acceptance of anthropogenic climate change information by reflecting on values. Risk Anal. 2014, 34, 929-936. [CrossRef] [PubMed]

92. Hobson, K.; Niemeyer, S. Public responses to climate change: The role of deliberation in building capacity for adaptive action. Glob. Environ. Chang. 2011, 21, 957-971. [CrossRef] 
93. Engels, A.; Hüther, O.; Schäfer, M.; Held, H. Public climate change skepticism, energy preferences and political participation. Glob. Environ. Chang. 2013, 23, 1018-1027. [CrossRef]

94. Grundmann, R. Climate change and knowledge politics. Environ. Politics 2007, 16, 414-432. [CrossRef]

95. Hornsey, M.J.; Harris, E.A.; Bain, P.G.; Fielding, K.S. Meta-analyses of the determinants and outcomes of belief in climate change. Nat. Clim. Chang. 2016, 6, 622-627. [CrossRef]

96. Guy, S.; Kashima, Y.; Walker, I.; O’Neill, S. Investigating the effects of knowledge and ideology on climate change beliefs. Eur. J. Soc. Psychol. 2014, 44, 421-429. [CrossRef]

97. Hart, P.S.; Feldman, L. The influence of climate change efficacy messages and efficacy beliefs on intended political participation. PLoS ONE 2016, 11, e0157658. [CrossRef] [PubMed]

98. Feola, G.; Lerner, A.M.; Jain, M.; Montefrio, M.J.F.; Nicholas, K.A. Researching farmer behavior in climate change adaptation and sustainable agriculture: Lessons learned from five case studies. J. Rural Stud. 2015, 39, 74-84. [CrossRef]

99. Weber, E.U.; Stern, P.C. Public understanding of climate change in the United States. Am. Psychol. 2011, 66, 315-328. [CrossRef] [PubMed]

100. Hagen, B.; Middle, A.; Pijawka, D. European climate change perceptions: Public support for mitigation and adaptation policies. Environ. Policy Gov. 2016, 26, 170-183. [CrossRef]

101. Torabi, N.; Mata, L.; Gordon, A.; Garrard, G.; Wescott, W.; Dettmann, P.; Bekessy, S.A. The money or the trees: What drives landholders' participation in biodiverse carbon plantings? Glob. Ecol. Conserv. 2016, 7, 1-11. [CrossRef]

102. Moser, S.C. Communicating climate change: History, challenges, process and future directions. Wiley Interdiscip. Rev. Clim. Chang. 2010, 1,31-53. [CrossRef]

103. Gavin, N.T.; Marshall, T. Mediated climate change in Britain: Scepticism on the web and on television around Copenhagen. Glob. Environ. Chang. 2011, 21, 1035-1044. [CrossRef]

104. Barnes, A.P.; Islam, M.; Toma, L. Heterogeneity in climate change risk perception amongst dairy farmers: A latent class clustering analysis. Appl. Geogr. 2013, 41, 105-115. [CrossRef]

105. Khanian, M.; Marshall, N.; Zakerhaghighi, K.; Salimi, M.; Naghdi, A. Transforming agriculture to climate change in Famenin County, West Iran through a focus on environmental, economic and social factors. Weather Clim. Extrem. 2018, 21, 52-64. [CrossRef]

106. Hamilton, L.C.; Lemcke-Stampone, M.; Grimm, C. Cold winters warming? Perceptions of climate change in the North Country. Weather Clim. Soc. 2018, 10, 641-652. [CrossRef]

107. Visschers, V. Public perception pf uncertainties within climate change science. Risk Anal. 2018, 38, 43-55. [CrossRef] [PubMed]

108. Jylhä, K.; Tuomenvirta, H.; Ruosteenoja, K.; Niemi-Hugaerts, H.; Keisu, K.; Karhu, J.A. Observed and projected future shifts of climatic zones in Europe and their use to visualize climate change information. Weather Clim. Soc. 2010, 2, 148-167. [CrossRef]

109. Capstick, S.B.; Pidgeon, N.F. What is climate change scepticism? Examination of the concept using a mixed methods study of the UK public. Glob. Environ. Chang. 2014, 24, 389-401. [CrossRef]

110. Libarkin, J.C.; Gold, A.U.; Harris, S.E.; McNeal, K.S.; Bowles, R.P. A new, valid measure of climate change understanding: Associations with risk perception. Clim. Chang. 2018, 150, 403-416. [CrossRef]

111. Wolf, J.; Allice, I.; Bell, T. Values, climate change, and implications for adaptation: Evidence from two communities in Labrador, Canada. Glob. Environ. Chang. 2013, 23, 548-562. [CrossRef]

112. Rohat, G.; Goyette, S.; Flacke, J. Twin climate cities-An exploratory study of their potential use for awareness-raising and urban adaptation. Mitig. Adapt. Strateg. Glob. Chang. 2017, 22, 929-945. [CrossRef]

113. Corry, O.; Jorgensen, O. Beyond 'deniers' and 'believers': Towards a map of the politics of climate change. Glob. Environ. Chang. 2015, 32, 165-174. [CrossRef]

114. Artur, L.; Hilhorst, D. Everyday realities of climate change adaptation in Mozambique. Glob. Environ. Chang. 2012, 22, 529-536. [CrossRef]

115. Mertz, O.; Mbow, C.; Reenberg, A.; Diouf, A. Farmers' perceptions of climate change and agricultural adaptation strategies in rural Sahel. Environ. Manag. 2009, 43, 804-816. [CrossRef]

116. Onencan, A.M.; Van de Walle, B. From Paris Agreement to action: Enhancing climate change familiarity and situation awareness. Sustainability 2018, 10, 1929. [CrossRef]

117. Rohat, G.; Goyette, S.; Flacke, J. Characterization of European cities' climate shift-An exploratory study based on climate analogues. Int. J. Clim. Chang. Strat. Manag. 2018, 10, 428-452. [CrossRef] 
118. Ogalleh, S.A.; Vogl, C.R.; Eitzinger, J.; Hauser, M. Local perceptions and responses to climate change and variability: The case of Laikipia District, Kenya. Sustainability 2012, 4, 3302-3325. [CrossRef]

119. Ayal, D.Y.; Filho, W.L. Farmers' perceptions of climate variability and its adverse impacts on crop and livestock production in Ethiopia. J. Arid Environ. 2017, 140, 20-28. [CrossRef]

120. Gifford, R. The dragons of inaction: Psychological barriers that limit climate change mitigation and adaptation. Am. Psychol. 2011, 66, 290-302. [CrossRef] [PubMed]

121. Lacroix, K.; Gifford, R. Psychological barriers to energy conservation behavior: The role of worldviews and climate change risk perception. Environ. Behav. 2018, 50, 749-780. [CrossRef]

(C) 2018 by the authors. Licensee MDPI, Basel, Switzerland. This article is an open access article distributed under the terms and conditions of the Creative Commons Attribution (CC BY) license (http://creativecommons.org/licenses/by/4.0/). 